DOI: $10.20472 / I A C .2019 .048 .042$

\author{
CEM OZISIK \\ ISTANBUL KULTUR UNIVERSITY, Turkey
}

\title{
TEACHER CANDIDATES - THE SOONER THE BETTER?
}

\begin{abstract}
:
Considering the teacher training undergraduate programs prepared by Turkish Board of Higher Education, students in English Language Teaching departments in Turkey do not have a chance to experience a real classroom setting until they take the course titled "Teaching Practice", which is offered in the final - 4th - year. With the belief that theory must be simultaneously supported with practice, an innovative approach is used in the Department of English Language Teaching (ELT) in the Education Faculty of İstanbul Kültür University (IKU), where teacher candidates start getting first-hand experience from the very beginning - the 1st year. This study evaluates this approach, comprised of four steps, which enable students to get engaged in real life classroom and teaching settings as well as gaining hands-on experience. Carried out with a qualitative aspect, the study went on for three years involving the current $2 \mathrm{nd}$, 3rd and 4th year students in the ELT department. After each step; namely, 'classroom observation, teacher interviews, school visits, and actual teaching', three research questions were asked: "How was your experience?", "What did you learn?", "In what way do you think this experience will contribute to you as a future teacher?" Feedback was received from the students in the form of written reflection reports and transcriptions of focus group meetings held regularly in groups of 10-15 on a voluntary basis. Common themes about each step were sorted out from the data and supported by actual words of students. The findings suggest that these four steps contribute to teacher candidates' attitudes towards teaching profession in that they start to internalize what they learn theoretically and will probably end up forming their own teaching philosophy thanks to a great variety of input they receive throughout this process.
\end{abstract}

\section{Keywords:}

Teacher Training, Teacher Candidates, Real Classroom Settings, Hands-on Experience.

JEL Classification: 129 